\title{
Curiosity and Instruction: British and Irish Botanic Gardens and their Audiences, 1760-1800
}

\author{
CLARE HICKMAN
}

Department of History and Archaeology

University of Chester

Parkgate Campus, Chester CH1 4BJ, UK

Email: c.hickman@chester.ac.uk

ORCID: 0000-0003-3356-5721

\begin{abstract}
The physic garden, associated with medical institutions and predominantly for the purpose of training medical students, or for the growing of commercial drugs by apothecaries, was transformed across Europe in the late-eighteenth century. New botanic gardens were created that were organised for the benefit of new audiences extending beyond medical students to those interested in botanical science, agricultural improvements and seeing at first-hand new botanic introductions from around the globe.
\end{abstract}

\section{KEYWORDS}

Botany, medicine, garden design, agriculture, collections

This article will examine four gardens established in Britain and Ireland between 1760 and 1800: the institutional botanic garden at Leith Walk, Edinburgh, opened in 1768 by John Hope; John Coakley Lettsom's private garden at Camberwell, London, established from 1779; William Curtis's semi-public London botanic garden, which moved locations in south London (originally opened in 1779), and the public Botanic Gardens in Glasnevin, Dublin, opened in 1796. These represent a spectrum of botanic collections, allow an exploration of the diversity of intended audiences, and offer examples of the main different types of collection in terms of ownership and accessibility: institutional, private, semi-public and public. They are also landscapes in which the 


\section{CLARE HICKMAN}

sciences of agriculture and botany both shape and are shaped by shifting tastes in garden aesthetics.

\section{INTRODUCTION}

In 1782, Dr John Hope, physician, botanist and superintendent of the Leith Walk botanic garden in Edinburgh, published the following advertisement:

Whereas much inconvenience has arisen from the crowds of promiscuous Company walking in the Botanic Garden by which the necessary work has been interrupted and proper distinction of visitors could not be made. On these and other accounts it has become necessary to admit none without an order from the Professor of Botany. By this regulation it is not meant to render access to the Garden difficult. Strangers, the Gentlemen of this county, the citizens of Edinburgh, and any person of knowledge or curiosity upon sending their names to the shops of: Mr Thomson Druggists, head of Niddry's Wynd; Mr Sparkie opposite the Tron Church; and Mr Moncrieff Apothecary on the Bridge; will receive an order for seeing the Garden, between the hours of twelve and three and, during summer, at 6 in the evening every day, Sunday excepted. ${ }^{1}$

The need for entrance tickets to manage visitors indicates that botanic or physic gardens, like country houses of the period, had become fashionable places to visit, in this case by what Hope considered to be 'promiscuous company' as well as learned and gentlemanly guests. The promiscuous appellation also alerts the reader to the fears Hope had regarding indiscriminate and casual visitors who would interrupt the main activities of the botanic garden - the teaching of botany to medical and other interested students. It is also clear that Hope's preferred public audience would be assembled from a mixture of the local gentry and serious botanists.

One can imagine that Hope would have sympathised with Horace Walpole, Whig politician and garden designer, who wrote about his home at Strawberry Hill that 'I am tormented all day and every day by people that come to see my house'. ${ }^{2}$ Like Hope, Walpole developed his own ticketing system with rules for admission as a way to manage the burgeoning interest in country house visiting as a leisure activity, a concern which Adrian Tinniswood has described in detail. ${ }^{3}$ Ticketing, however, could be unpopular with visitors. In 1776 the Hon. Mrs Boscawen complained to Mrs Delany regarding her reception at Lady Di. Beauclerc's on Muswell Hill', describing that

'tho' we met her ladyship taking an airing, and that Mr. Beauclerc was in town, yet they would not admit us to see the conservatory (which was all we aspir'd

1. 'Botanic Garden', Caledonian Mercury, 4 May 1782.

2. Adrian Tinniswood, The Polite Tourist: A History of Country House Visiting (London: National Trust, 1998), pp. 91-112.

3. Tinniswood, p. 91 


\section{CURIOSITY AND INSTRUCTION}

to) without a ticket. Resistance you know, always makes one more obstinate, so Mrs Leveson has wrote to Sr Joshua Reynolds to beg he will obtain this necessary passport. ${ }^{4}$

As this demonstrates, in this period there could be a very fine line between private and public spaces. Botanic gardens, in their various guises, whether private, subscription or institutional, seem to have also had both public and private audiences.

Unlike Hope, who attempted to limit visitors, William Curtis's London Botanic Garden, which was funded by subscription from the 1770 s, necessarily had a broader paying audience in mind. In his Proposal written to attract subscribers, Curtis stated that the garden was 'designed for the use of the physician, the Apothecary, the student in Physic, the scientific Farmer, the Botanist (particularly the English Botanist,) the lover of Flowers and the Public in general. ${ }^{5}$ This comprehensive list of botanic audiences will be used in this article to reconfigure our understanding of how botanic gardens developed in response to different audiences, rather than focusing on their design features or detailed description of plants.

Given that plant collections could be private, institutional or public in nature, it is worth considering what defined a botanic garden as separate from other designed spaces. In 1820, the gardener, designer and writer John Claudius Loudon delineated types of gardens in terms of their audience. He wrote that:

gardening is practised for private use and enjoyment, in cottages, villas, and mansion gardens; - for public recreation, in umbrageous and verdant promenades, parks, and other scenes, in and near to large towns; - for public instruction, in botanic and experimental gardens; - for public example, in national or royal gardens; - and for the purpose of commerce, in market, orchard, seed, physic, florists', and nursery gardens. ${ }^{6}$

This focus on the type of audience provides the framework for considering botanic gardens and their users in this period of change, when botanic gardens shifted from being predominately educational to more public facing places.

4. The Hon Mrs Boscawen to Mrs Delany, 14 Oct. 1776 in Lady Augusta Llanover (ed.), The Autobiography and Correspondence of Mary Granville, Mrs. Delany: with Interesting Reminiscences of King George the Third and Queen Charlotte (London: Bentley, 1862), Second Series, 3 vols, III, pp. 264-5

5. Curtis, Proposals, title page

6. John Claudius Loudon, An Encyclopaedia of Gardening: Comprising the Theory and Practice of Horticulture, Floriculture, Arboriculture, and Landscape-gardening, Including All the Latest Improvements; a General History of Gardening in All Countries; and a Statistical View of Its Present State, with Suggestions for Its Future Progress in the British Isles (London: Longman, Hurst, Rees, Orme, Brown, and Green, 1824), p. 1. He also felt that the main element distinguishing a botanic garden from other designed spaces was its organisation according to a scientific system. Later in Encyclopaedia he argued that 'scientific assemblages of plants or botanic gardens appear to have been unknown to Romans who had formed no regular system of nomenclature for the vegetable kingdom', p. 17. 


\section{CLARE HICKMAN}

According to Loudon, botanic, like experimental, gardens were denoted as being for the 'instruction' of the public, and made distinct from 'physic' gardens with their commercial connotations. This denotes an important shift that occurs towards the end of the eighteenth century, also identified by Nuala Johnson and Therese O'Malley. ${ }^{7}$ As Johnson has noted, the developing science of botany impacted on the way that gardens ordered nature so as to better reflect scientific understanding. ${ }^{8}$

Leith Walk was associated with the University of Edinburgh and funded predominately by Government funds and student fees. Lettsom's garden was his domestic residence and, although privately funded, was also publicly accessible. In contrast, Curtis's garden was funded by subscribers and aimed to fulfil their diverse needs, while Glasnevin was created by a Society interested in all forms of improvement, but particularly that which could be achieved through agricultural change. These descriptions were not fixed, nor did accessibility remain the same. Like many spaces in the eighteenth century, botanic gardens were highly porous and fluid.

This research builds particularly on the work of Paul Elliott, who has expertly considered the eighteenth-century relationship between spaces and science in Britain, as well as Johnson and O'Malley's interrogations of the development of botanic gardens in the eighteenth century in relation to artistic, scientific and political change. ${ }^{9}$ Elliott's research in particular has demonstrated that botanical gardens 'became cardinal and characteristic Enlightenment spaces, idealised microcosms where the concerns of improvement, medicine and systematic botany and botanical publishing intersected with commercial gardening, polite education and fashionable promenading'. ${ }^{10}$ Focusing on garden visitors and the way garden managers oversaw this burgeoning leisure activity makes visible other intersections. Private gardens and institutional collections start to look similar to commercial nurseries, as all offered the interested public access to view, and sometimes even take away, physical plant specimens.

7. Nuala Johnson, Nature Displaced, Nature Displayed: Order And Beauty In Botanical Gardens (London: I.B. Tauris 2011); Therese O'Malley, 'Art and science in the design of botanic gardens, 1730-1830’, Garden History: Issues, Approaches, Methods (1992): 279-302.

8. Johnson, Nature Displaced, p. 6.

9. Paul Elliott, Enlightenment, Modernity and Science: Geographies of Scientific Culture and Improvement in Georgian England (London and New York: I.B. Taurus, 2010); and Elliott, British Urban Trees: a Social and Cultural History, c. 1800-1914 (Winwick: The White Horse Press, 2016).

10. Elliott, Enlightenment, Modernity and Science, p. 125. 


\section{THE PHYSICIAN, THE APOTHECARY AND THE STUDENT IN PHYSIC}

Medical students have historically constituted the main audience utilising botanic or physic gardens associated with Universities. ${ }^{11}$ According to Johnson, the aim of early botanic gardens, such as that established at Padua in 1545, 'was to enhance the knowledge of and education in plants for training doctors so that they could prescribe and prepare drugs for patients more readily'. ${ }^{2}$ It is perhaps not surprising that John Hill's 1758 treatise, An Idea of a Botanical Garden in England, argued that London needed to establish a botanic garden in order to keep medical students at home rather than travelling to the Continent for training. He felt that there was particular competition for such students from classes led by Herman Boerhaave, Professor of Physic and Botany at Leiden, and Albrecht von Haller, Professor of Anatomy, Botany and Surgery in Gottingen. Botany, according to Hill, was still primarily a skill that medical students needed to learn, although he did also mention the use of plants for dyes and bemoaned the fact that in England botany was not yet recognised as 'a science of utility'. ${ }^{13}$

Hill's solution to the lack of a suitable garden in London was to suggest that Kensington Palace be developed for this purpose. Based on the organisation of the Jardin du Roi in Paris, this would be funded from the Royal purse, with free lectures on botany given on Saturdays when the King was absent. ${ }^{14}$ Kensington, in Hill's plan, would become a worthy rival to the French botanic garden and become at once an ornamental garden suitable for a British monarch to enjoy and a scientific and educational enterprise - perhaps the ultimate example of the botanic garden as it would be designed for both utile and dulce. This is a central idea that we will return to later. Rather than develop a garden at Kensington, Hill instead obtained an unofficial position at Kew, under his patron Lord Bute, and produced the first catalogue of plants being grown there by the Dowager Princess of Wales in $1768 .{ }^{15}$ Only later did Kew develop into the type of scientific institution Hill envisaged.

Edinburgh's Leith Walk garden actually fulfilled many of Hill's aims, albeit without a resident monarch and being created much further north. However, unlike Hill's Royal institution, the Leith Walk garden was closely associated with a medical faculty via its founder, Hope, and followed in much the same

11. Physic gardens for training medical students and apothecaries became popular after the establishment of Padua in 1545, appearing in Rome in 1566, Zurich in 1561, Lyons in 1564, Bologna in 1567, Montpellier in 1598, Paris in 1640, the University of Oxford in 1621 and the Chelsea Physic Garden in 1673. See Johnson, Nature Displaced.

12. Johnson, Nature Displaced, p.3.

13. John Hill, An Idea of a Botanical Garden in England (London: R. Baldwin, 1758), p. 5.

14. Hill, An Idea, p. 8.

15. John Hill, Hortus Kewensis, sistens herbas exoticas, indigenasque rariores, in area botanica hortorum Augustissimae Principissae Cambriae Dotissae apud Kew in Comitatu Surreiano cultas (London: Ricardum Baldwin, 1768) 


\section{CLARE HICKMAN}

vein as its continental and British predecessors, including the botanic gardens at Padua, Pisa, Montpellier, Leiden and Oxford. Hope, a member of the medical faculty at Edinburgh University, had his garden designed with the central aim of teaching botany to medical students. ${ }^{16}$ Having been awarded the joint chair in Botany and Materia Medica in Edinburgh, and King's botanist for Scotland and Superintendent of the Royal Garden in 1761, Hope successfully lobbied for a new, larger botanic garden in the mid-1760s. ${ }^{17}$

The Leith Walk garden was designed explicitly for teaching Hope's everincreasing number of students. According to Henry Noltie, 'more than 1700 men attended Hope's lectures in Botany (1761-1786) and Materia Medica (1761-1767)' ${ }^{18}$ A novel physical feature of this enterprise was the botanic cottage, which was built into the external wall of the garden. This functioned as both a lecture room (upstairs) and residence for the head gardener and his family (downstairs). The garden itself was an essential teaching tool and Noltie has argued that Leith Walk represented 'a permanent teaching and research institute of a new type, inspired by the ideas of Joseph Pitton de Tournefort and the brothers Antoine and Bernard de Jussieu, as enshrined at the Jardin du Roi in Paris' ${ }^{19}$ Given that Hope visited European centres of botany before successfully petitioning for a garden in Edinburgh, such continental stimuli must have influenced his design. This continental experience, particularly studying under the eminent French naturalist Bernard de Jussieu, may also explain the importance that Hope placed on botany as a subject in its own right. By 1768 Hope had successfully passed the Materia Medica teaching part of his professorship over to the eminent physician and chemist Francis Home. At that point Hope became the first Regius Professor of Botany at the University of Edinburgh and was able to focus solely on that subject.

\section{THE BOTANIST}

It is perhaps not surprising, then, that Hope saw wider botanic knowledge, as distinct from that useful in medical practice, as important in its own right and developed courses aimed at a new botanically focused student. In his petition

16. More detail on John Hope and the Leith walk garden can be found in H.J. Noltie, John Hope (1725-1786): Alan G. Morton's Memoir of a Scottish Botanist (Edinburgh: RBGE, 2011)

17. At the time of Hope's appointment, Edinburgh already had two seventeenth-century physic gardens: the first was created adjacent to Holyrood Palace in 1670 and the second at Trinity Hospital, in 1676, so his aim was to combine the two collections on a new purpose built site.

18. Noltie, John Hope, p. 84.

19. Noltie, John Hope, p. 18. Noltie also notes that when Hope travelled to Europe as a medical student in the 1740s he chose Paris over Leiden because he wished to study under de Jussieu because of his interest in botany (p. 9). See Emma Spary, Utopia's Garden: French Natural History from Old Regime to Revolution (Chicago: Chicago University Press, 2000) for a detailed and enlightening exploration of the various political, social and scientific roles played by the Jardin du Roi. 


\section{CURIOSITY AND INSTRUCTION}

requesting government funds for the foundation of his garden, Hope argued that

the benefit which arises to every school of medicine from a complete Botanic Garden is great \& apparent from the great number of Physicians \& Surgeons which have already gone from this University into the Fleet, Army, Colonies \& many other parts of His Majesty's dominions, renders it an object it is hop'd not unworthy of His Majesty's favour and protection. ${ }^{20}$

Here Hope makes the case for the importance of a garden for teaching medical students by relating it to the economic benefits that would accrue from the new plant material being sent home by military surgeons and physicians. Richard Drayton has demonstrated that concerns over national economy were strong drivers for the creation of imperial botanic gardens in this period and that support for the creation of the Royal Gardens at Kew was given in the hope that 'the exploitation of Nature might supply food, raw materials, "new branches of trade and commerce". ${ }^{21}$ There was also a particular Scottish dimension to these economic concerns. As Fredrik Albritton Jonsson has argued, the push for improvement in Scotland in particular, was often based on a goal of national self-sufficiency. ${ }^{22}$ As Hope was one of those interested in this movement it was perhaps not surprising that his Leith Walk botanic garden included space for trees, which had economic value, and other potentially lucrative plants, such as rhubarb. ${ }^{23}$

This concern with national economy was perhaps also reflected in the range of people taking John Hope's botany course. A list of students from 1763 indicated that the following already took his botany course and not all were medical students. It registered a knight, two ministers, a captain, druggists, advocates, Americans and some noted simply as 'Infirmary'. ${ }^{24}$ According to Noltie, over the period of Hope's tenure, 77 students came from North America, 35 from the West Indies, and 21 from other European countries such as Switzerland, Germany and Spain. ${ }^{25}$

The garden's design itself also perhaps physically demonstrated Hope's shift into a botany- rather than physic-centred method of teaching. ${ }^{26}$ Like Boerhaave's garden at Leiden, which O'Malley has described as being laid

20. Undated, c.1766, PRO, T1/445/286.

21. Richard Drayton, Nature's Government: Science, Imperial Britain and the 'Improvement' of the World (New Haven: Yale University Press, 2000), p. 80.

22. Fredrik Albritton Jonsson, 'Scottish Tobacco and Rhubarb: The Natural Order of Civil Cameralism in the Scottish Enlightenment', Eighteenth-Century Studies 49 (2) (2016): 129-147.

23. Ibid.

24. RGBE archives, GD/253/144/8

25. Noltie, John Hope, p. 86.

26. For a detailed examination of the history and design of the garden see Johanna LausenHiggins, 'Sylva Botanica: Evaluation of the lost eighteenth-century Leith Walk Botanic Garden Edinburgh', Garden History 43 (2) (2015): 218-236. 
out with geometric regularity to emphasise Boerhaave's own system of ordering plants, the design of Hope's garden also appears to have reflected his own particular scientific focus on the creation and dissemination of botanical knowledge. ${ }^{27}$ At Leith Walk the traditional medicinal plant beds of regimented straight lines used for teaching only formed a small portion of the garden scheme, known as the 'Schola Botanica', and were relegated to one side of the plot. The core design in front of the main glasshouses was more elaborate. From extant plans, it appears to have incorporated an organic layout with a series of paths shaped around beds as following the outline of a poppy seed head [Fig. 1]. As Johanna Lausen-Higgins has argued, with its informal beds and winding walks, we can also regard the garden as an example of current landscape gardening tastes. ${ }^{28}$

This seems to be very different from the more rigid and formal designs found in the earlier University botanic gardens such as Padua, Pisa, Uppsala, Montpellier and Oxford, although, as O'Malley has delineated, even the design of these apparently rigid gardens went beyond strictly instructive purposes as is clear from the complexity of their plans. ${ }^{29}$ She has also noted that, by the eighteenth century, botanic gardens were being adapted in order to place plants in artificial reconstructions of the natural environments in which they were discovered..$^{30}$ The scientific need for formal layouts to display taxonomic relationships was clearly only one factor influencing botanic garden design. It is likely that these changes in the idea of how plants should be displayed, as well as changing conceptions of domestic garden design, played a role in Hope's more stylistically informal design. ${ }^{31}$

Sadly, there is little in the archives to indicate how the garden space was received by those students attending Hope's courses. However, there are indications that, unlike earlier lecturers of botany for medical students, Hope seems to have viewed knowledge of the medicinal uses of plants of secondary importance. His contemporary Hugo Arnot in 1789 recorded that:

In the first part of his course, he treats of vegetation, several parts of which he explains by a variety of experiments in the Botanic Garden. In the second he unfolds the botanical system, and treats fully of the natural order of plants. The third is devoted to the explanation of the nature and use of exotic plants, the whole being concluded with a history of botany ... and the students in general, have freer access to the garden, than is permitted in foreign universities. ${ }^{32}$

27. O’Malley, 'Art and science', 287.

28. Lausen-Higgins, 'Sylva Botanica', 218-236.

29. Ibid., 284.

30. Ibid., 294. See also Nuala C. Johnson, 'Cultivating science and planting beauty: the spaces of display in Cambridge's botanical gardens', Interdisciplinary Science Reviews 31 (1) (2006): $42-57$.

31. See Lausen-Higgins, 'Sylva Botanica'.

32. Hugo Arnot, History of Edinburgh (Edinburgh, W. Creech; London J Murray, 1789), p. 402 


\section{CURIOSITY AND INSTRUCTION}

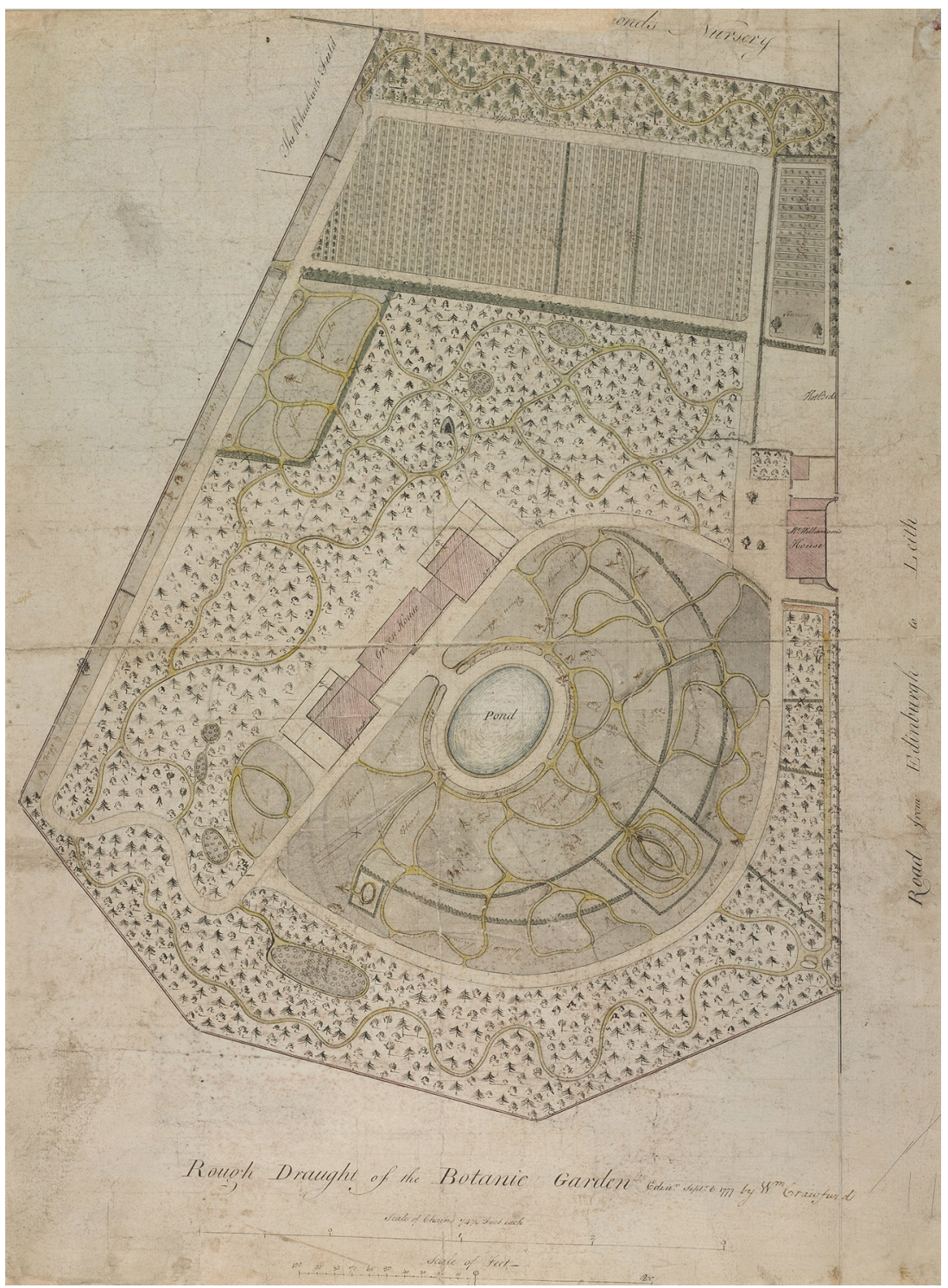

Figure 1. 1777 plan of the Leith Walk garden showing the regimented lines of the Schola Botanica at the top of the image and the winding paths with poppy seed motif to the right of the pond. The botanic cottage which has now been moved and reconstructed at the RGBE is the coloured red building to the right hand side by the perimeter wall. Royal Botanic Gardens Edinburgh Archives (A77). 


\section{CLARE HICKMAN}

This perhaps marked a change in the use of such gardens and their role as botanical rather than simply medicinal resources. Following publication of Linneaus' Philosophia botanica in 1751 (and the nurseryman James Lee's English summary of the text which was reprinted eight times between 1760 and 1811), there was a growing interest in botany as a scientific system. ${ }^{33}$ Hope, Lettsom and Curtis all laid out part of their gardens according to this system, with Hope even installing a monument to Linneaus in the Leith Walk garden in $1779 .{ }^{34}$ As Lisbet Koerner has described in depth, Linneaus also highlighted the economic advantages which could potentially accrue from understanding this new botanic knowledge, which made it of even greater interest. ${ }^{35}$

Notes made by Hope's students and now located in the RBGE archives, also highlight that the predominant focus of his course was botanical science. This evidence fits O'Malley's argument that in this period botanic gardens 'which had hitherto been primarily medicinal in purpose, became museums of living plants and centers for research experiment, display and delight' ${ }^{36}$ In the notes Hope reflected this by stating that in the third [part of the course] we shall examine the plants in the garden beginning with the most simple \& there we shall touch lightly on their uses in Medicine'. ${ }^{37} \mathrm{He}$ also noted his desire in the third part of the course to 'hold up to [the students'] view the different things in the Garden. ${ }^{38}$ So the garden provided material that could be brought into the classroom for teaching purposes as well as a place where plant specimens could be viewed closely.

However, the use of the garden for teaching did come with problems, as the student body taking the course grew. According to the notes, Hope described how the third:

\& last part of the course consists in demonstration, in this part I have made some improvement \& in others I have given it up entirely, for a no. walking thro' the Garden, especially in bad weather I found to be of great injury to it. It is impossible for you to have access to the Exotic plants but by demonstration yet many of the Exotics do not come to such perfection as to admit of demonstration. ${ }^{39}$

So the plants, if left in situ, could be damaged by ever-increasing numbers of students trying to view them and even attempts to bring specimens indoors to

33. Lisbet Koerner, Linneaus: Nature and Nation (Cambridge: Harvard University Press, 1999), p. 14.

34. Noltie, John Hill, pp. 54-55.

35. Koerner goes so far as to argue that 'Linnaeus' binomials resulted from his attempts to practice science as an auxiliary branch of economics, and from this efforts to create a simple language for it', p. 43.

36. O’Malley, 'Art and science', 299

37. Francis Buchanan, Hope's Botany: Notes taken from Dr. John Hope's lectures on botany, Summer 1780, RGBE archives.

38. Anon, Lectures on Botany, p. 3.

39. Ibid. 


\section{CURIOSITY AND INSTRUCTION}

protect the plants could be thwarted by their inability to acclimatise and produce successful blooms in the garden.

The laying out of gardens according to taxonomic understanding was not confined solely to the types of University-related botanic gardens exemplified by Edinburgh. In his Proposals Curtis describes how he had applied Linnaeus' new taxonomic language to his collection: "to each plan in the garden, is affixed its generic and trivial name, according to LINNAEUS: and that none may lose the advantage of acquiring a knowledge of plants from a nonacquaintance with the Latin, the English names also are added'.$^{40}$ The use of English alongside Latin emphasises the educational role of such gardens in relation to new botanical methods of organisation.

Similarly, one of the many subscribers and early supporters of Curtis' garden, John Coakley Lettsom, created a private botanic garden laid out according to Linnaean principles within his small estate of Grove Hill in Camberwell [Fig. 2]. As a leading physician of the period, he could afford a townhouse near his practice in the city of London as well as a small rural estate in Camberwell. ${ }^{41}$ Like many other physicians of this period, including Drs Pitcairn and Fothergill (Lettsom's mentor), he established his own botanic garden and agricultural research station. Having regularly frequented Fothergill's estate at Upton, Lettsom purchased 2,000 botanical specimens with greenhouses, transferring them to Grove Hill on the elder physician's death in $1780 .^{42}$ According to Penelope Hunting, who has described the features of Lettsom's garden in some detail, 'by 1792 he had enlarged the property by 10 acres, landscaped the grounds, planted an arbustrum (as he called the plantation), through which a walk led to Cupid's portico, the Observatory known as the Temple of the Sibylls, the rotunda, a statue of Shakespeare and Fountain cottage'. ${ }^{43}$ All this symbolised a man of taste with an interest in that great hobby of the period, landscape gardening. Within this picturesque landscape was his botanic garden.

As Loudon would no doubt have approved, Lettsom described how one of his garden 'compartments is allotted to exotick, and of these chiefly American shrubs, the other principally to a range of rare English plants, and to each is annexed the linage and English names'. ${ }^{44}$ Again, like Curtis, this demonstrates the educational role of gardens and their appeal to a broad audience. Lettsom's biographer Pettigrew suggested that 'any person, however ignorant of practical

40. Curtis, Proposals, pp. 8-9.

41. By 1800, his practice reaped an incredible annual income of around £12,000. J.F. Payne, 'Lettsom, John Coakley (1744-1815)', rev. Roy Porter, first published 2004, Oxford Biography Index Number 101016527.

42. Penelope Hunting, 'Dr John Coakley Lettsom, Plant-Collector of Camberwell', Garden History 34 (2) (2006): 221-235, at p. 222.

43. Ibid., 223.

44. John Coakley Lettsom, Grove-Hill, An horticultural sketch (London: Printed for the Author, 1794), Royal Society Archive, Tracts X99/3. 


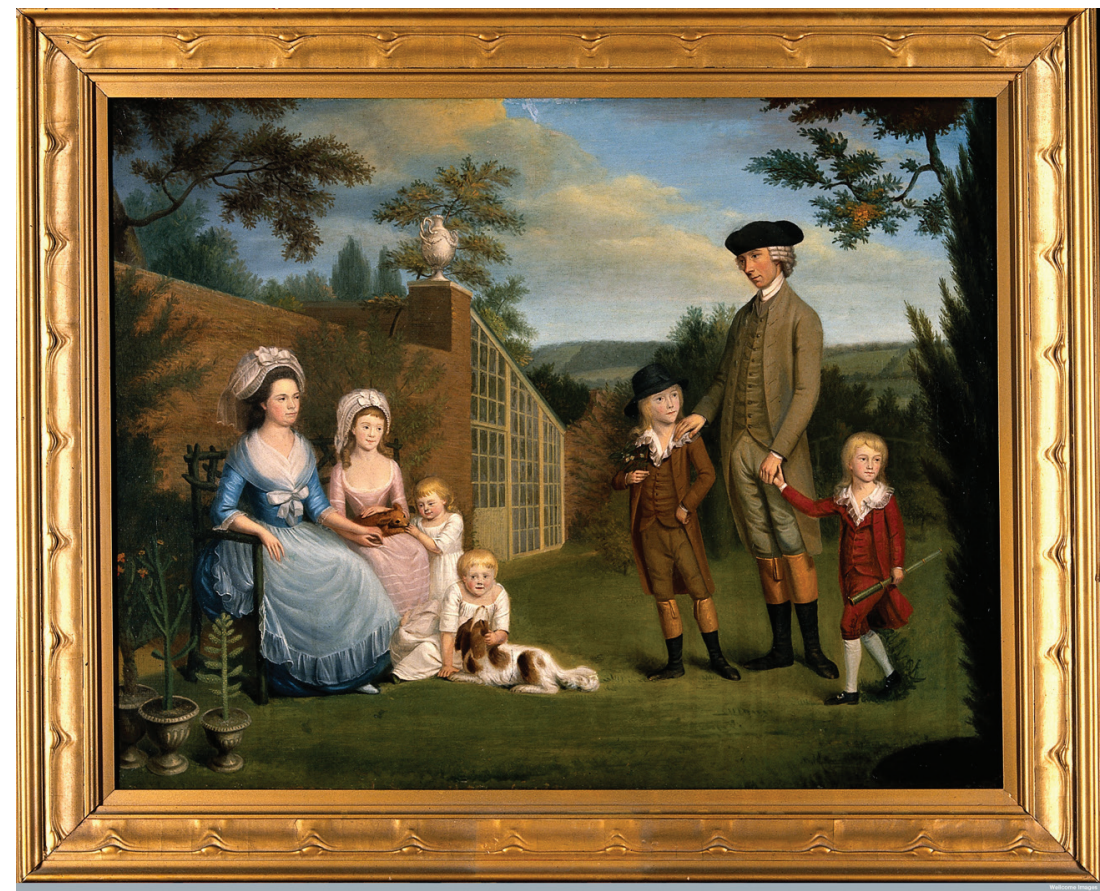

Figure 2. London John Coakley Lettsom (1733-1810), physician, with his family, in the garden of Grove Hill, Camberwell, ca. 1786. Note the glass house, and the botanical specimens in ornamental urns in the foreground. Wellcome Library.

botany, might acquire a tolerably correct idea of that valuable science, by a due attention to the arrangements, \&c. of this garden'. ${ }^{45}$ This suggests that there was a scientific and educational purpose behind the ordering of plants, as well as perhaps at the same time highlighting Lettsom's own expert knowledge of botany.

\section{THE SCIENTIFIC FARMER}

As with many other botanists of the day, Lettsom did not confine his interest to ornamental plants but also took an interest in agriculture. Not only did he promote the Mangel Wurzel (a cross between a turnip and a beetroot newly introduced to the UK) through pamphlets and the exchange of seeds, he also

45. Thomas Joseph Pettigrew, Memoirs of the Life and Writings of John Coakley Lettsom (London: Nichols, Son and Bentley, 1817) 3 vols, I, p.167. 


\section{CURIOSITY AND INSTRUCTION}

grew the plant in his garden. ${ }^{46}$ This interest in agricultural experimentation within domestic settings is reflected in this letter from Glasgow physician, William Cullen to the London physician William Hunter in 1788:

I have got a farm, and if the public would not laugh, I would call it a villa. It is truly a scheme of pleasure not profit. I hope indeed to make two stalks of corn grow where one grew before; but I believe this will be of more benefit to the public than myself and my purpose is purely the beauty of strong corns and fine grass. ${ }^{47}$

It should be noted that he hoped to create a highly fashionable and ornamental style of farm, known as a ferme ornée in which to conduct his agricultural trials. One of the archetypal gardens designed in this manner was by William Shenstone at the Leasowes and in the same letter, Cullen goes on to say that, 'I hope, in short, in a few years to shew a Leasowes in Scotland.' ${ }^{48}$ According to Lausen-Higgins, Hope also visited the Leasowes and was interested in its design, which suggests an inter-relationship between botanic gardens and ornamental farms at this time. ${ }^{49}$

This interest in experimental and ornamental farming was evidently fashionable and so landed gentry with an interest in new agricultural practices would also have been likely audiences for botanic gardens. Curtis argued that the botanic improvement encouraged by the "nobility, gentlemen of landed property, and public societies, fully aware of its importance, and endeavouring by premiums and a variety of other means', would not be 'crowned with success, till botany is more cultivated, and plants, particularly the grasses, better understood' ${ }^{50}$

The importance of agriculture in the design and use of botanic gardens seems to have increased dramatically from the 1760 s onwards. This shift was related to the founding of societies with economic interests such as the Society for the Encouragement of Arts, Manufactures and Commerce in 1754 (whose motto incidentally was utile et dulce) and the creation of agricultural societies, including the Bath agricultural society in 1774, which had its own experimental garden. Over in Dublin, the focus of the new botanic garden at Glasnevin was definitively agricultural, partly due to the involvement of the Dublin Society, established in 1731 to improve the poor economic condition of the country by promoting agriculture, arts, industry and science in Ireland. This was also in

46. Lettsom, An Account of the Culture and Use of the Mangle Wurzle or Root of Scarcity, Translated from the French of the Abbe De Commerell, (London: Printed for Charles Dilly, 1787), pp. v-vi.

47. John Thompson, An Account of the Life, Lectures and Writings of William Cullen (Edinburgh: William Blackwood, 1832), Vol. 1 of 2, p. 565

48. Ibid.

49. Lausen-Higgins, 'Sylva Botanica', 230.

50. Curtis, Proposals, p. 7. Curtis himself wrote a number of botanic texts including a tract on the Practical Observations on the British Grasses, published in 1790. 


\section{CLARE HICKMAN}

line with its key instigator John Foster's personal interests, which were more allied to national economic success rather than scientific concerns. ${ }^{51}$

According to Finola O'Kane,

the desire for a public garden lay in its instigators' wish to educate both their peers and the common man and to disseminate as widely as possible the economic and social benefit wrought by improvement; improvement being part and parcel of both colonization and the rising capital economy. This gave the new foundation distinctly nationalist and competitive overtones. ${ }^{52}$

This reflects some of the impetus seen behind the calls for new botanic gardens as expressed by Hill in relation to London, Hope in Edinburgh and, as we shall see below, the gentlemen of Norwich. However, Dublin's garden also reflected local concerns specific to the region and the players involved.

The Prospectus for Dublin's Botanic Garden of around 1795 included various areas devoted to different agricultural activities, including a cattle garden and a hay garden. ${ }^{53}$ The prospectus described the areas' intended uses and audience - illiterate husbandmen:

These hay and cattle gardens are proposed for the instruction of the practical husbandman, he will there see every Plant, Shrub and Weed which grows in Ireland; he will see at once, what are useful, what otherwise, for each Animal; he will learn how to weed his meadows and pastures, how to select the Hay Seeds which should be sown together and what Weeds on his Ditches or Tillage grounds he should be most anxious to prevent seeding; and the most illiterate Man is capable of Instruction from these, by being told what is the Description of the Division he looks at.

Like the other gardens explored in this essay, the physical botanic collection was not the only form of knowledge dissemination. The prospectus also notes that, 'there shall be a professor who shall give Lectures on Botany in general; and also separate Lectures on the Cattle and Hay gardens for the Instruction of common farmers, their Servants, or Labouring Men, all of whom are to be admitted to the Lectures gratis' ${ }^{54}$ This resonates with the London Botanic Garden, in which Curtis gave lectures to subscribers, and of course Hope's botanic lectures for students. However, there was evidently at least an expectation that the Dublin audience would be more mixed in nature and that those from the labouring classes could attend such sessions for free. The lectures

51. A detailed description of the creation of Glasnevin Botanic Garden, and Foster's role, appears in Charles Nelson and Eileen McCracken, The Brightest Jewel: A History of the National Botanic Gardens, Glasnevin, Dublin (Kilkenny: Boethius, 1987); and Johnson, Nature Displaced.

52. Finola O'Kane, 'The Irish Botanical Garden: for Ireland or for Empire?' Studies in the History of Gardens and Designed Landscapes 28 (3-4) (2008): 446-455, at p. 446.

53. PRONI D562/7829 C Prospectus for the Dublin Society's Botanic Garden, giving an account of the sections into which it will be divided. C.1795

54. Ibid. 


\section{CURIOSITY AND INSTRUCTION}

here would also stand as replacements for the important guides and associated texts that more literate audiences would be expected to read alongside the specimens.

\section{THE LOVER OF FLOWERS AND THE PUBLIC IN GENERAL}

Of course, even the Dublin botanic garden was also aimed at those of higher classes than the agricultural labourer. The growth in exotic botanic specimens led to a level of excitement relating to novel species that made them both newsworthy and attractive to garden visitors. For example, the flowering of a Rheum palmatum in a Norwich schoolmaster's garden was reported in 1766 with the statement that it was the first time that the plant had flowered in Britain outside of the Edinburgh Botanic Garden, where it had flowered the year before ${ }^{55} \mathrm{~A}$ report of the Great American Aloe flowering at the Edinburgh Botanic Garden a year later was accompanied by set opening hours for visitors. ${ }^{56}$ The fact that such events were worthy of reporting and also came with hours when such blooms could be viewed, highlights the general interest in novel botanic specimens. Such stories no doubt also encouraged a growing and increasingly mobile Enlightenment public to see the exotic for themselves. From this perspective the type of garden was perhaps of less interest than the novelty of the species it contained. To the public looking for 'curiosity and instruction', nurseries, private gardens and institutional botanic gardens were all of equal interest as they allowed audiences to view the flora for themselves.

The growth in overseas plants and the interest they generated stimulated the establishment of a variety of different botanic collections. Like many eighteenth-century projects, subscription could also fund such living collections. In London this model resulted in the establishment of Curtis's London Botanic Garden. Curtis, an apothecary by trade, had worked as a demonstrator for the Worshipful Company of Apothecaries at Chelsea Physic Garden. He founded the Botanic Magazine; or Flower-Garden Displayed (begun in 1787 and the UK's longest continually running magazine). According to Kath Clark, Curtis met Lettsom and Fothergill to discuss the concept of establishing a subscription botanic garden for the purpose of teaching botany in London in $1770 .{ }^{57}$

The subscription idea was not unique to London-based apothecaries and physicians. In June 1779, the Norfolk Chronicle reported that 'a number of gentlemen ... are desirous of establishing a Botanical Garden near this City, upon the most liberal and perfect Plan' ${ }^{58}$ The Norfolk gentlemen argued that

55. Country News, Leeds Intelligencer, 20 May 1766.

56. Advertisement, Caledonian Mercury, 18 Nov. 1767

57. Kath Clark, 'William Curtis's London Botanic Gardens and Flora Londinensis', The London Gardener 15 (2009-10): 26-34

58. Norfolk Chronicle, 19 June 1779.

Environment and History 24.1 


\section{CLARE HICKMAN}

they could raise enough by 'admitting Subscribers of One Guinea per year, to visit the Garden, from Ten O'Clock till One, in the Winter Season, and from Two till Seven in the Summer'. ${ }^{59}$ This highlights the fashionable nature of botanic gardens, the perceived scientific importance of such spaces and a sense of regional and civic pride that such establishments could engender. ${ }^{60}$

In 1778 Curtis produced a pamphlet requesting subscriptions for his garden, then based in Lambeth Marsh. ${ }^{61}$ The notes for subscribers stated that for two guineas a year they could access the garden on four set days of the week and bring one guest with them. As a garden that relied upon subscriptions for its survival, it was evidently hoping to fulfil a perceived need for an accessible botanic collection in London. According to Elliott, 'sixteen per cent of the subscribers listed in 1790 were women acting in their own name, but many more would have gained admission as family members of friends'. ${ }^{62}$ This suggests a portion of the audience were interested in developing polite knowledge and highlights the fashionable nature of garden-visiting.

The Leith Walk garden also reflected a convergence between increased desire for both polite and popular knowledge, with Hope attempting to manage this burgeoning interest by implementing his ticketing system, referred to above. As one of his students recorded, Hope argued that the

the taste for natural History is now become universal, \& particularly for the study of Botany. The no. of Interesting plants in this Garden is daily increasing. Coffee, Scammony, Camphor, the Indian pink, \& the most wonderful of all, the moving plant are in great perfection. ${ }^{63}$

Interest in the botanic garden was being fed by the novel and interesting plants arriving from around the Empire and his precious blooms were being threatened by both an increase in scholarly, student interest and a growing popular interest in these productions of Empire.

It wasn't just the introduction of novel and exotic species that piqued such interest. The concept of 'improvement', and in particular agricultural developments, were also fashionable interests. Sarah Tarlow has demonstrated how broad ideas of late-eighteenth and early nineteenth-century 'improvement' impacted on a range of features, from agricultural interests through civic architecture to workhouses and prisons. She has argued that, 'the economic and moral meanings of the term became increasingly knitted together so that by the mid-eighteenth century "Improvement" meant both profit and moral benefit' ${ }^{64}$

59. Ibid.

60. See Liverpool (1802) and Hull (1812) botanic gardens; more detail on both can be found in Elliott, Enlightenment, pp. 153-163.

61. As Clark notes, Curtis' garden moved sites several times during its existence.

62. Elliott, Enlightenment, p.142.

63. Ibid.

64. Sarah Tarlow The Archaeology of Improvement in Britain, 1750-1850 (Cambridge: Cambridge University Press, 2007), p. 12 


\section{CURIOSITY AND INSTRUCTION}

Using this definition, the late eighteenth-century botanic garden can be viewed as a space able to bring both economic and moral benefits. They were educational, with their attempts to classify and disseminate information about plants, as well as providing spaces where economically viable plants could be showcased alongside methods for increasing crop production.

This is not to say that improvement was separate from the ornamental within the landscape. As Tom Williamson has argued 'contemporaries used the term [improvement] "indiscriminately" for the reclamation of "waste", for schemes of afforestation, and for the laying out of parks and elaborate pleasure grounds'. ${ }^{65}$ Reflecting this dual interest in profit and ornamental improvements, the twin terms, 'dulci' and 'utile', were often expressed by those writing about botanic gardens. As Curtis asserted in 1778, botany was 'among all the studies which engage mankind, there are none more pleasing, more extensive, or in which the utile dulci is so intimately blended' ${ }^{66}$ As Sarah Easterby-Smith and Emily Senior have elucidated, this was related to wider concerns regarding the production of natural knowledge: "the dual focus on "use" and "beauty" is evident across the range of fields of natural knowledge, and was related to both the form in which knowledge was expressed and the types of practitioner who created or engaged with such knowledge'. ${ }^{67}$ Gardens, and in particular botanic gardens, then became the ideal spaces in which their owners could both create and disseminate natural knowledge related to both beauty and utility.

Many botanic gardens combined agricultural experiments with beds of exotic specimens. The more conventional ornamental gardens expressed similar combinations of economic and scientific interests. Williamson has described how 'in 1801 John Lawrence urged that parks should, together with the home farm, be used as a "theatre for the display of all the notable varieties of experimental husbandry". ${ }^{68}$ Therefore, the spectacle of agricultural experiment could also be part of the eighteenth-century landscape visiting experience. Similarly, Arthur Young recorded the Marchioness of Salisbury's experimental garden at Hatfield in his General View of Agriculture of Hertfordshire for the Board of Agriculture (1804), describing how

the cleanness of the crops their flourishing luxuriance the general aspect of the whole are truly pleasing. I could not, however but regret that a register had not been kept of every crop, the expense, produce and consumption per acre; this field would then not have yielded pleasure only but an ample harvest of agricultural knowledge and with a few variations easy to have devised would have

65. Tom Williamson, The Transformation of Rural England: Farming and the Landscape, 17001870 (Exeter: University of Exeter Press, 2002), p. 19.

66. William Curtis, Proposals for Opening by Subscription a Botanic Garden to be Called the London Botanic Garden, (London: J. Andrews for the Author, 1778), p. 4

67. Sarah Easterby-Smith and Emily Senior, 'The Cultural Production of Knowledge: Contexts, Terms, Themes', Journal for Eighteenth Century Studies 36 (4) (2013): 471-543, at p. 471.

68. Tom Williamson, Polite Landscapes: Parks and Gardens in Georgian England. (Stroud: Alan Sutton, 1995), p. 122 


\section{CLARE HICKMAN}

produced a fund of important conclusions. The thought had great merit and I cordially wish the field to be so productive of pleasure to its Mistress as to give charms to the country sufficient to rival the great foe to experiment - London. ${ }^{69}$

As well as highlighting a rural/urban divide, the Marchioness's interest appears, on the surface at least, to have reflected fashionable pursuits rather than serious scientific interest. There was certainly a courtly interest in botany and agricultural improvements under George III. ${ }^{70}$ That setter of trends, the King, not only erected his own model farm adjacent to the Richmond Gardens, ${ }^{71}$ but also wrote letters to Arthur Young describing agricultural experiments taking place at Windsor under a pseudonym in $1787 .{ }^{72}$ It is no surprise that gardens with botanic, agricultural and scientific aims were flourishing at the end of the eighteenth century and proving to be attractive spaces for visitors.

In what seems to be a clear nod to the activities of the Royal family at Kew and Richmond, Lettsom included an observatory containing scientific instruments in his garden along with his equally fashionable exotic plants and agricultural experiments. As we shall see, Lettsom intended a wide range of people to visit his garden and sought to create a physical, living example of the scientific and improving interests of the age. In a published guide to his estate, he stated that he had received requests for information regarding the design of his garden following its being featured in Edwards A Companion from London to Brightelmston, in Sussex..$^{73}$ The Companion included topographical maps, plans, and views of country houses, as well describing the "natural history and antiquities of all the towns, village, gentleman's seats, \&c on the road and circumjacent from London to Brightelmston'74. This handy guide also included lists of inns with details of post-chaises, 'stage-coaches, stage waggons and other vehicle inns; with their usual hours of passing to and from London' ${ }^{75}$ It was, therefore, catering to a middling and upper-class audience interested in travel for leisure. The fact that Lettsom's garden was listed alongside more elite

69. Arthur Young and General Board of Agriculture, General View of the Agriculture of Hertfordshire: Drawn Up for the Consideration of the Board of Agriculture and Internal Improvement (London: G. and W. Nicol, 1804), pp. 233-4.

70. John Gascoigne, Science in the Service of Empire: Joseph Banks, the British State and the Uses of Science in the Age of Revolution (Cambridge: CUP, 1998), p. 130

71. Drayton, Nature's Government, p. 88. For more on the political appropriation of both farming and the idea of improvement see pp.148-151

72. For more on the King's interest in agriculture see Drayton, Nature's Government, pp. 87-89.

73. James Edwards, Tabulae Distantiae; or, Two Tables of Lineal Distances (Description of Southwark, Lambeth, Newington, \&c, Companion from London to Brighthelmston) (Dorking, 1789).

74. Ibid.

75. Ibid. 


\section{CURIOSITY AND INSTRUCTION}

landscapes created by the gentry suggests that he had commissioned a garden that was considered fashionable and of interest to the travelling public. ${ }^{76}$

Sadly, we do not know who these visitors were, but we do know that they were able to gain access to the garden, despite Lettsom's busy medical practice in the City. In 1800 he wrote to the Reverend Plumtre describing how,

the Camberwell postman lives in my lodge, that opens Grove-Hill; he has the residence for the trouble of opening the gate. I am rarely there, as my professional duties oblige me to remain a denizen of the metropolis. ${ }^{77}$

Writing to a fellow agriculturalist ten years earlier, he had already complained that

the numerous avocations which confine me for weeks successively in London, prevent me from that accuracy of experiment which ought to precede publicity. Add to this, that my villa being in the vicinity of London, numerous visitors ambulate my premises, and beg, or pluck up, some of the objects of experiment. ${ }^{78}$

These letters indicate that he was always struggling to manage his busy practice and rarely spending the time he would have liked at Camberwell, and that his garden was both a place for his own experimentation and a popular resort with visitors who even took specimens away with them.

As this latter letter was written in 1790 , before publication of his own guide, news of his botanic collection had evidently already travelled via the republic of letters, and through the publicity created by its inclusion in Edwards Companion in 1789, and such articles as published in the European Magazine and London Review in May 1788. Lettsom himself noted that his garden's popularity was in part due to its proximity to London, with its eager audience for botanical curiosities and easy availability of mechanisms for travel.

He keenly promoted his own garden, as the subscription to Edwards' Companion suggests. At the start of his own guide he wrote that,

however inapplicable the following relation may be to the improvement of spacious premises, it may tend in some measure with the annexed notes to assist the proprietors of country houses, in possession only of small allotments of garden ground, in laying them out in a style equally ornamental and productive ... but few are formed without being capable of more or less improvement, with respect to ornament as well as agricultural oeconomy. ${ }^{79}$

So it would seem that he considered his garden to be a model for others and one which combined those key eighteenth-century ideals of dulci and utile.

76. Lettsom was one of the subscribers to Edwards' Companion, so other motives may have been at play. Lettsom may have wanted his garden to be advertised in order to emphasise his gentlemanly status, or it could have been a nod from Edwards to a patron.

77. Letter from Lettsom to Rev. J Plumtre, 1 Dec. 1800 in Pettigrew, Memoirs, II, pp. 106-107.

78. Lettsom to Sir Mordaunt Martin, 13 Mar. 1790 in Pettigrew, Memoirs, II, p. 24.

79. Lettsom, Grove-Hill. 


\section{CLARE HICKMAN}

As many eighteenth-century spaces could function as both private and public places, it is unsurprising that Lettsom's botanic collection was also the background for sociable meetings with his contemporaries, including the Athenaeum club who often visited Grove Hill. Writing to Plumtre in 1800, Lettsom recorded how, "my wife likes the country, where I dine with her, usually every Sunday, with a party of select friends, and now and then sleep there'. ${ }^{80}$ James Boswell, biographer and diarist, immortalised one sociable Saturday afternoon playing bowls with Lettsom at Camberwell in a poem published in $1791 .^{81} \mathrm{He}$ described Lettsom's wide-ranging interests, including the Mangel Wurzel, which suggests that these were displayed during their sociable occasions:

In Fossils he

Is deep, we see

Nor knows Beasts, Fishes, Birds ill;

With Plants not few

Some from Pelew

And wond'rous Mangel-Wurzel! ${ }^{82}$

This illustrates the role of the garden as a backdrop to sociable meetings and exchanges of polite knowledge as well as a more public space for casual visitors. Other more ornamental spaces in the garden were no doubt used for these meetings but the more scientific spaces formed by the botanic garden, along with the observatory, library and museum must also have been an important part of such private encounters. As Michael Brown has demonstrated 'agricultural knowledge was polite knowledge' and, along with other forms of natural history, expertise such as botany could be used to build influential 'kinship networks' and raise the societal status of those involved. ${ }^{83}$ Botanical specimen exchange cemented such kinship networks. London Botanic Garden received donated plants from George III's garden at Kew, and the gardens of the Earl of Bute, Duchess Dowager of Portland, Dr Fothergill, Dr Pitcairn and the Apothecaries Company. ${ }^{84}$ Curtis also credits the nurserymen Messrs Gordon, Lee, Kennedy and Malcolm. These examples suggest the existence of a network that crossed private, institutional and commercial botanical collections.

We can find the same connections, if we move away from our usual understanding of botanic gardens, and consider how visitors and collectors used such spaces. Mrs Delany describes visiting the Chelsea Physic Garden, Dr Fothergill and Pitcairn's private gardens and Mr Lee's nursery over a period of

80. From Pettigrew, Memoirs, vol II, pp. 106-107.

81. Gentleman's Magazine, Apr. 1791, p. 367

82. Ibid.

83. Michael Brown, Performing Medicine: Medical Culture and Identity in Provincial England, c. 1760-1850, (Manchester: University Press, 2011), p. 56

84. Curtis, Proposal, p. 10. 


\section{CURIOSITY AND INSTRUCTION}

a few days in $1779 .{ }^{85}$ There is nothing to distinguish between the gardens in her writing; she viewed them all as places where she could find new and interesting specimens. ${ }^{86}$ She also records taking specimens from the Physic Garden as well as from the doctors' private collections. Yet from Mr Lee's nursery she returns with nothing, recording, with a disappointed tone, that the only flower of interest at that time to her was 'a crinum, a sort of Pancratium'.${ }^{87}$ This experience aside, we do know that Lee, even though a commercial nurseryman, did give away duplicate specimens as well as sell them. According to Dr Thornton, Lee's biographer, his nursery garden was 'always open to the curious; nor was he ever backward in communicating knowledge ... He chose rather to give duplicates away to lovers of Botany, before the selling of them to the rich and careless collectors of flowers.' ${ }^{88}$

\section{CONCLUSION}

The exchange of polite knowledge, with its benefits for the creation of influential networks, created by the dissemination of physical specimens, was, then, shared by nurserymen, as well as more traditional botanic garden-managers and those owning private collections. At Dublin, a note in the 1796 prospectus states that for 'the purpose of extending Practical Knowledge, particularly in Husbandry, Samples and Seeds be allowed to be given, and even Plants, where they can be'. ${ }^{89}$ These types of transmission could also potentially extend beyond polite circles to the labouring classes. Similarly, botanic gardens could sell plant material themselves, blurring the distinction between commercial and educational enterprises. In 1799, Curtis and his successor Salisbury printed a catalogue of seeds available to buy from the Botanic Nursery (presumably related to the Botanic Garden which by that time was in Brompton). ${ }^{90}$ The printing of catalogues could represent both a collection guide and a sales list. Lettsom's guide to his garden was supplemented in 1804 by a catalogue of his trees and shrubs.

85. See Llanover, The Autobiography and Correspondence, Second series, Vol II.

86. These specimens she recreated as detailed, realistic paper collages. During her lifetime she created thousands such collages and her collection is now held in the British Museum. For more on Mrs Delany and her botanical interests see Mark Laird and Alicia Weisberg-Roberts, Mrs Delany and her Circle (New Haven: Yale University Press, 2009).

87. Llanover, The Autobiography and Correspondence, Second series, Vol II, 11 May, 1780, p. 519.

88. Robert Thornton, Introduction to James Lee, An Introduction to the Science of Botany, Chiefly Extracted from the Works of Linneaus to which are added, several new tables and notes and A life of the Author (London: Printed for F.C. and J. Rivington; etc, 1810), p. xv.

89. PRONI D562/7829 C Prospectus, c.1795.

90. A Catalogue of Seeds \&c. Sold by Curtis and Salisbury at the Botanic Nursery, Queen's Elm Turnpike, Brompton (1799). 
When considering botanic collections, it is worth straying outside the walled enclosure of the traditional institutional or society garden to consider how the curious, as well as those looking for instruction, encountered specimens. It also becomes clear that the spaces operated in both public and private spheres and that they could be negotiated differently by different audiences. They also combined the beautiful and ornamental with the utilitarian. The complex negotiation that current botanic gardens make between scientific and public audiences and their attempts to combine the educational with the pleasurable can be seen to have their roots in the gardens of the late eighteenth century. Hope, with his ticketing system for the public and attempts to manage student numbers in a fragile environment, will no doubt resonate with current botanic garden managers.

\section{ACKNOWLEDGEMENTS}

The research for this work was funded by a Wellcome Trust Postdoctoral Fellowship in Medical History and Humanities (WT 100388MA). Thanks go to Alice Marples and Victoria Pickering for inviting me to discuss the initial stages of this work at the 'Collections in Use' workshop at King's College London in 2015 and I am indebted to the expert comments from the audience in general and Neil Pemberton in particular. 